\title{
The impact of rising temperatures on water balance and phenology of European beech (Fagus sylvatica L.) stands
}

\author{
Klaus Dolschak ${ }^{1} \cdot$ Karl Gartner $^{2} \cdot$ Torsten W. Berger $^{1}$ \\ Received: 27 November 2018 / Accepted: 6 May 2019 / Published online: 22 May 2019 \\ (c) The Author(s) 2019
}

\begin{abstract}
In this article, we outline the set-up and the application of an eco-hydrological box model, with the aim to describe the water balance of deciduous (Fagus Sylvatica L.) forest stands. The water balance model (WBM) uses standard meteorological parameters as input variables and runs on a daily time step. It consists of two modules. The aboveground module (1) comprises routines for fog precipitation generation, precipitation interception and snowfall/snowmelt dynamics. Covered belowground processes (2) are bypass flow, percolation, soil evaporation and transpiration, where the latter two processes are considered separately. Preceding to the WBM, a routine is introduced, specifying the intra-annual foliage dynamics of beech. Emphasis is also laid on the inter-annual variation of beech phenology. Leaf sprouting and leaf senescence are calculated as functions of day-length and air temperature. The WBM was applied to four European beech dominated forest stands in the northeastern part of Austria. They are located on a gradient of declining annual precipitation (from west to east). The two easterly sites are located close to the (dry) limit of the natural distribution of beech. Records of soil moisture were used for the adjustment of 26 parameters. On all sites the calibration process (simulated annealing) delivered good predictions of soil moisture (Nash-Sutcliffe efficiency $\geq 0.925$ ). Then, the obtained parameterization was used to apply different scenarios of global warming. The temperature was increased step-wisely up to $4{ }^{\circ} \mathrm{C}$. All scenarios were run (1) with present phenological conditions and (2) with phenology responding to higher temperatures. This way, we wanted to assign the effect of higher temperatures and longer growing seasons on the water dynamics of the forest stands. A warming of $1{ }^{\circ} \mathrm{C}$ corresponded roughly to an elongation of the growing season of 4.5 days, where the start of the growing season was affected more strongly than the end. Apparently, higher temperatures led to drier soils. The strongest change was observed in early summer, also amplified by an earlier start of the growing season. Rising temperatures led to lower export fluxes of liquid water, simultaneously increasing evapotranspiration (ET). The gain in ET was almost entirely assignable to increased soil evaporation. Drier soils led to a sharp depression of transpiration during summer months. This decline was compensated by the effect of elongated growing seasons. The risk of severe drought was increased by higher temperatures, but here the contribution of growing season length was negligible. Drier soils seem to hamper the stands' productivity. For all warming scenarios, the estimated increase of the gross primary production, caused by longer periods of assimilation, is nullified by the effect of soil water deficit in mid-summer.
\end{abstract}

Keywords Forest water balance $\cdot$ Box model $\cdot$ Soil drought $\cdot$ Climate change $\cdot$ Beech phenology $\cdot$ Simulated annealing

Electronic supplementary material The online version of this article (https://doi.org/10.1007/s40808-019-00602-1) contains supplementary material, which is available to authorized users.

Klaus Dolschak

klaus.dolschak@gmx.at

Extended author information available on the last page of the article

\section{Introduction}

Climate change is assumed to have a strong impact on Central European forest ecosystems. Over the last 140 years, South Europe and the Alps experienced a temperature increase of $2{ }^{\circ} \mathrm{C}$ (Mayer et al. 2005). Current climate estimations point to a further rise of the global surface temperature of $2{ }^{\circ} \mathrm{C}$ in the next 40 years (Field et al. 2014); it seems likely that the alpine region will experience a temperature elevation which will even be stronger (EEA 2015). Beech 
is a dominant tree species in Central and Western European forests (Dittmar et al. 2003); the natural distribution is associated to the Atlantic to Sub-continental Climate (Sutmöller et al. 2008). As a species with a broad eco-physiological amplitude, it seems adequately adapted to resist climate change in the (humid and cool) Atlantic areal of distribution (Kölling et al. 2007). Especially on the southern limit of the species' distribution a different picture is expected. There, the occurrence of beech is mainly restricted by the soil water availability (Ellenberg and Leuschner 1996). European Beech is a species which is particularly vulnerable to soil drought (Bolte et al. 2009). Dry and hot conditions have been known to restrict net primary production of beech forests significantly (Ciais et al. 2005). Higher temperatures are assumed to increase the frequency and intensity of soil drought due to the forcing effect on potential evapotranspiration (Bergh et al. 2003). In contrast to rising temperatures, annual precipitation sums are assumed to retain the present level, but there might be a shift in the seasonal pattern. Current estimations point towards increasing late-winter to spring precipitation, hand in hand with decreased precipitation during summer months (Geßler et al. 2007; Kunstmann et al. 2004), exacerbating soil water deficit.

Warmer conditions will lead to a temporal elongation of the growing season of beech (Vitasse et al. 2009). Under optimal conditions this would result in an increased productivity (Lindner et al. 2010). Under water limitation the opposite effect seems possible. High temperatures in spring favor growth at first. Later in the season they accelerate the soil water depletion, resulting in a sharp drop of carbon fixation by mid-summer (Dittmar et al. 2003; Kljun et al. 2007; Richardson et al. 2013).

A future increase of frequency and duration of drought periods during the growing season might alter the productivity, competitive and regenerative abilities of beech stands, especially on shallow soils (Geßler et al. 2007; Rennenberg et al. 2004). On these sites, it seems likely that beech stands will be replaced by drought resilient Oak-Hornbeam forest associations (Theurillat and Guisan 2001).

In this work, we set up a model describing the water balance of deciduous forest stands. The routing of modeled water fluxes is illustrated in Figure $\mathrm{S} 1$ of the supplementary. Due to a strong connection of processes such as light extinction, precipitation interception or the stands water demand to the stands leaf area (van Wijk and Williams 2005), we see the need to describe the temporal dynamics of the vegetation cover. Preceding to the WBM, a phenological routine is introduced, consisting of 2 elements: (1) the calculation of inter-annual variations of leaf emergence and leaf senescence, and (2) a quantitative measure, describing the stands seasonal development of the leaf area.

This way we assessed the soil moisture dynamics of four beech stands, which are located in the north-easterly part of Austria, close to the dry distribution limit of European beech. We analyzed the effect of climate change on the sites' water balance. In that context, possible changes in $\mathrm{CO}_{2}$ air concentration or the precipitation pattern were neglected; the focus lay solely on the impact of rising temperatures on the stands' soil moisture regime. This way, we assessed temperature driven changes of the frequency and intensity of soil water deficit. At last we tried to identify factors which were influencing the stands' vulnerability and resilience towards soil drought.

\section{Materials and methods}

\section{Study sites}

The investigated forest stands are located in the north-easterly part of Austria in the foothills of the Northern Calcareous Alps (see Fig. 1b). The parent material for soil formation is Flysch, which consists of old tertiary and mesozoic sandstones and clayey marls of maritime origin. Due to high clay

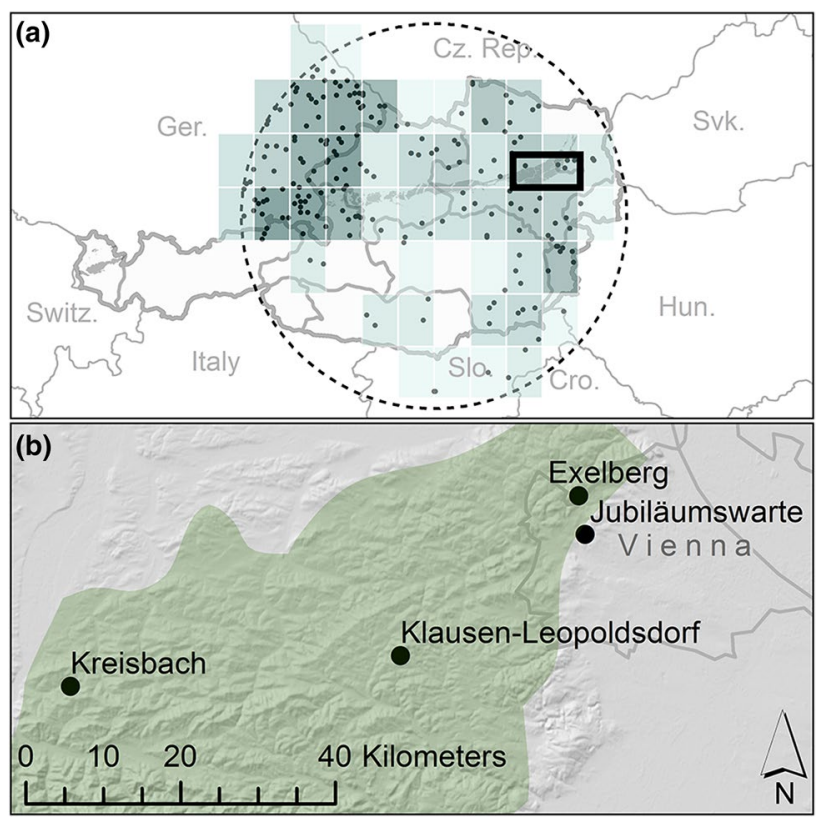

Fig. 1 a For calibration of the phenological model, PEP725 (Pan European Phenology Data) beech stands (small black dots) were accessed within a radius of $200 \mathrm{~km}$ centered to $47^{\circ} 42^{\prime} 00^{\prime \prime} \mathrm{N}$, $14^{\circ} 30^{\prime} 00^{\prime \prime} \mathrm{E}$. One average time series of air temperature was calculated, using data from the E-OBS gridded dataset (Tank et al. 2002b) $\left(0.5^{\circ}\right.$ resolution, turquoise rectangles). The frequency of selected sites within one grid cell defines the relative weight, the cell receives in the calculation of the average; darker cells correspond to higher weightings. b Locations, used in the calibration of the WBM (black dots). All sites are beech dominated stands and share their geological bedrock (flysch). The green area represents the natural distribution of European Beech according to the Map of the Natural Vegetation of Europe (Bohn et al. 2004) 
content, the saturated hydraulic conductivity is low, leading to frequent episodes of waterlogging. Therefore, the soil type can be classified as stagnic cambisol according to the WRB soil classification (IUSS Working Group 2006) throughout all studied sites. The mean annual temperature in the study area is approximately $9{ }^{\circ} \mathrm{C}$. Precipitation declines from west to east, with average annual sums ranging from $820 \mathrm{~mm}$ (Kreisbach) to $652 \mathrm{~mm}$ (Vienna).

In the framework of the International Co-operative Programme on Assessment and Monitoring of Air Pollution Effects on Forests (ICP Forests), the Austrian Research Centre for Forests operates several intensively monitored forest sites (Level II) (Neumann et al. 2001). In addition to other environmental parameters, meteorological conditions are monitored continuously. Soil moisture (Campbell CS615 FDR probe) is recorded at 3 different depths $(15,30,60 \mathrm{~cm})$.

The model was originally set up on data from the Level II plot Klausen-Leopoldsdorf (KL), which is located in the Vienna Woods ( $\left.48^{\circ} 07^{\prime} 16^{\prime \prime} \mathrm{N}, 16^{\circ} 02^{\prime} 52^{\prime \prime} \mathrm{E}\right)$, at an elevation of $510 \mathrm{~m}$ a. s. 1. The research site is a pure beech (Fagus sylvatica $\mathrm{L}$.) stand, which was planted in the late thirties of the last century. The site is facing NE with an inclination of $20 \%$. The actual forest vegetation coincides with the potential natural one and can be classified as Hordelymo-Fagetum (Mucina et al. 1993). For a more detailed site description see Neumann et al. (2001).

The Kreisbach (KB) site, which is located south of St. Pölten $\left(48^{\circ} 05^{\prime} 50^{\prime \prime} \mathrm{N}, 15^{\circ} 39^{\prime} 50^{\prime \prime} \mathrm{E}\right)$ at an elevation of $470 \mathrm{~m}$ a. s 1., is a mixed European beech-Norway spruce (Picea abies L.) stand, with beech dominating. The stand is facing NNE with an inclination of $19 \%$. The natural plant association can be classified as Asperulo odorataeFagetum. From 1998 to 2003 the site was monitored meteorologically within the framework of a special research program on Forest Ecosystem Restoration. Soil moisture records (Trase1 TDR probe) exist for 4 different depths $(10,20,40,55 \mathrm{~cm})$. For a more detailed site description see Schume et al. (2003).

The third site (Jubiläumswarte, JU) is located within the municipal area of Vienna at the eastern edge of the Vienna Woods $\left(48^{\circ} 13^{\prime} 12^{\prime \prime} \mathrm{N}, 16^{\circ} 15^{\prime} 56^{\prime \prime} \mathrm{E}\right)$, at an elevation of $440 \mathrm{~m}$ a. s. 1 . The site, which is a pure beech stand with an estimated age of 125-150 years, is facing SSE with an inclination of $15 \%$. As a matured stand it is showing signs of collapse but also strong natural regeneration. Different to the other investigated sites, the bedrock contains calcareous material, reflected in higher base saturation and soil $\mathrm{pH}$.

The Exelberg (EX; 48 $\left.14^{\prime} 40^{\prime \prime} \mathrm{N}, 16^{\circ} 15^{\prime} 18^{\prime \prime} \mathrm{E}\right)$ site is located in Lower Austria close to the border to Vienna, $2.8 \mathrm{~km}$ northwest of Jubiläumswarte. This site is also a pure beech stand. We estimated the stands' age approximately 100 years. The site is also facing SE with an inclination of $22 \%$. Two years of bi-weekly observations of soil moisture exist for 10, 30 and $60 \mathrm{~cm}$ depth. The latter two sites are located at the dry distribution limit of beech (see Bohn et al. 2004). They receive significantly less precipitation than the first two. Due to their location at upper hill slopes and their exposition, we see them prone to soil drought.

\section{Data sources}

The WBM, which runs on a daily time step, uses standard meteorological data on a daily base as input. Time series of minimum $\left(T_{\min },{ }^{\circ} \mathrm{C}\right)$, mean $\left(T_{\text {mean }}\right)$ and maximum $\left(T_{\max }\right)$ temperature, the daily averages of relative humidity $(\mathrm{rH})$, global radiation $\left(\mathrm{gR}, \mathrm{wm}^{-2}\right)$, and wind speed at $2 \mathrm{~m}$ above ground $\left(u_{2}, \mathrm{~ms}^{-1}\right)$, as well as the observed 24 -h precipitation sum $\left(P_{\mathrm{obs}}, \mathrm{mm}\right)$ are required. The phenological module utilizes daily $T_{\text {mean }}$ and $T_{\max }$.

For gap filling purposes, data were accessed from the Austrian Meteorological Agency (ZAMG) as well as from the Austrian Hydrographic Service (eHYD). For the EX site, we accessed precipitation records from a private weather station. Missing data were replaced, using simple regression techniques, with data from highly correlated, neighboring stations.

For calibration of the phenological module, data were retrieved from the PEP725 database (PEP725 Pan European Phenology Data, data set accessed on 06/06/2015 at http://www.zamg.ac.at/pep725/). Two phenological stages were considered. (1) BBCH-11: leaf unfolding (LU) on the first visible leaf stalk, represents the onset of the growing season. (2) BBCH-94: autumnal leaf coloring (50\% of leaves colored) (LC), marking the end of the growing season. In this work, phenological phases are calculated as functions of day-length and air temperature. Therefore, the gridded E-OBS dataset (a daily gridded observational dataset for meteorological parameters) was accessed $\left(0.5^{\circ}\right.$, regular grid), provided by the European Climate Assessment (ECA\&D) (Tank et al. 2002a).

Due to strong site variations of phenological events, the set-up of the phenological model was conducted, utilizing multiple phenological sites within a radius of $200 \mathrm{~km}$, centered to $47^{\circ} 42^{\prime} 00^{\prime \prime} \mathrm{N}, 14^{\circ} 30^{\prime} 00^{\prime \prime} \mathrm{E}$ (see Fig. 1a). The phenological dataset was scanned for outliers using Tukey's test. Parallel data was checked for month-mistakes (Schaber and Badeck 2002). Only time series with 10 or more annual observations were considered in the calculation. To overcome site specific effects, the influence of phenotypic plasticity (Capdevielle-Vargas et al. 2015), or divergences in the assessment of phenological stages (Estrella and Menzel 2006), the calibration of the model was performed on an assembled time-series. To generate this assembled time-series, we implemented the 3rd method which was proposed in Häkkinen et al. (1995). To each DoY of each time-series a site wise offset $\left(O_{s}\right)$ was 
applied. The aim was minimizing the residual between site-wise time-series and the mean time-series over all sites:

$$
\min _{O_{\mathrm{s}}}\left[\sum_{y} \sum_{s}\left(\left(\mathrm{DoY}_{s y}-O_{s}\right)-\frac{\sum_{s}\left(\mathrm{DoY}_{s y}-O_{s}\right)}{n_{y}}\right)^{2}\right] .
$$

To achieve this, we used the classical hill climber algorithm. 40,000 iterations were used to adapt $O_{s}$ for all considered sites. The sum of squared residuals could be reduced to approximately $55 \%$ of its initial value. To ensure that the residual sum equals zero, the overall mean before and after the optimization was calculated; the difference between both means stated a second offset which was applied to $\mathrm{DoY}_{s y}$ :

$o_{n}=-\frac{\sum_{s y} O_{s}}{n_{s y}}$.

Parallel, a time-series of the average $T_{\text {min }}, T_{\text {mean }}$ and $T_{\max }$ was calculated over all E-OBS grid cells, comprising selected phenological sites, whereat the number of sites within the cell defined the relative weighting the cell received in the calculation of the average.

\section{Model description}

\section{Annual phenological key events}

Beech can be considered a late flushing species (Vitasse and Basler 2013). By that, it is following a rather conservative strategy, aiming to decrease the risk of late frost exposure (Caffarra and Donnelly 2011; Körner and Basler 2010). There are several environmental signals involved, in the triggering of the start of the growing season. Of high relevance is the seasonal course of the photoperiod (Basler and Körner 2012), meaning the day length has to exceed a critical threshold in spring before bud burst might occur (Körner and Basler 2010). According to Laube et al. (2014), an environmental trigger which is weighted even more strongly, is the chilling demand, meaning winter temperatures, undershooting a threshold for a certain time, are promoting dormancy release in spring. Furthermore, leaf sprouting is accelerated by high spring temperatures (Caffarra and Donnelly 2011; Vitasse et al. 2009).

Compared to spring phenology, the environmental triggering of beech senescence is less understood (Estrella and Menzel 2006; Vitasse et al. 2009). Especially the role of temperature is discussed controversially. For European beech stands, Estrella and Menzel (2006) reported positive correlation of the August and September mean air temperature, with the date of leaf coloring. Surprisingly, the authors found also a negative correlation with temperature in May and June, meaning low average temperatures in late summer and high temperatures in late spring promote the temporal occurrence of leaf senescence. Whether the latter was a direct temperature effect, or the effect of (temperature correlated) drought during critical phenological stages, was not examined.

In this section, a model is presented, describing the onset of the growing season as function of daily air temperature. Assuming the chilling demand generally over-satisfied for central European forest stands (Fu et al. 2012), only the forcing effect of air temperature is considered.

A common approach to quantify the forcing effect of air temperature on spring development requires the definition of a threshold temperature; below this temperature no forcing is taking place, above the temperature forcing is assumed proportional to the temperature difference between actual and threshold temperature (Cannell and Smith 1983). To achieve a more gradual transition of the forcing response to air temperature, a piecewise combination of a first and second order polynomial is presented in this work. The full formulation of the function, which is optically resembling the shape of a hockey stick, is stated in the "Appendix" (Eqs. 18, 23, 24). Below the threshold temperature $\left(T_{0, \mathrm{LU}}\right)$ the response is assumed 0 . The onset is described with a 2 nd order polynomial. A second key temperature $\left(T_{1, \mathrm{LU}}\right)$ defines the transition from quadratic to linear response, where $m_{\mathrm{LU}}$ sets the forcing rate at $T_{1, \mathrm{LU}}$. Most approaches for predicting spring phenology as a function of air temperature make use the daily mean temperature. In this work, it was found that the average of daily $T_{\text {mean }}$ and $T_{\max }$, aiming to represent the average daytime temperature $\left(T_{\text {day }}\right)$, displayed higher force of expression in the prediction of LU:

$f_{T}=\operatorname{hockey}\left(T_{\mathrm{day}}, T_{0, \mathrm{LU}}, T_{1, \mathrm{LU}}, 0, m_{\mathrm{LU}}\right)$.

Analogue to Blümel and Chmielewski (2012), a day length term is included, accounting for the photoperiodic influence on spring development. The day length ( $d l$, hours) was calculated as function of the day of the year (DoY) and the geographical latitude, analogue to Swift (1976). A model parameter in the exponent $\left(x_{\mathrm{LU}}\right)$ adds one degree of freedom. Preventing vast values in the photoperiod term, day length is normalized by dividing by $14 \mathrm{~h}$ :

$f_{d l}=\left(\frac{d l}{14 h}\right)^{x_{\mathrm{LU}}}$.

The daily forcing is described as the product of a function of air temperature and day length:

$f_{\mathrm{LU}}=f_{T} f_{d l}$. 
The temperature accumulation starts with $\mathrm{DoY}_{0, \mathrm{LU}} \cdot \mathrm{LU}$ is triggered after the accumulation of 10 forcing units:

$S f_{\mathrm{DoY} 1, \mathrm{LU}}=\sum_{\mathrm{DoY}}^{\mathrm{DoY}_{1, \mathrm{LU}}} f_{\mathrm{DoY}, \mathrm{DoY}}=10$.

The calibration of the model was conducted on the assembled time-series, described in the previous section. The phenological data which used in this work was provided in discrete daily resolution, but calculating means over several sites led to non-integer values for the day of the year of the phenological event. A model, which is treating phenological events as discrete in time, cannot overcome the residual caused by the decimal places. To surmount this minor but unnecessary flaw, another function is introduced: The difference of the sum, necessary to trigger budburst and the sum of the day prior to budburst, divided by the difference of the sum, achieved on the budburst day and the prior day, minus a half day is calculated:

$c_{\mathrm{LU}}=\frac{10-S f_{\mathrm{DoY} 1, \mathrm{LU}-1}}{S f_{\mathrm{DoY} 1, \mathrm{LU}}-S f_{\mathrm{DoY} 1, \mathrm{LU}-1}}-\frac{1}{2}$.

A distinct exceeding of the temperature sum, necessary to trigger the event, on DoY $\mathrm{Y}_{1, \mathrm{LU}}$ will result in a negative value of $c_{\mathrm{LU}}$, Therefore, DoY $\mathrm{LU}_{\mathrm{LU}}$ will be shifted to a slightly earlier point of time. A weak overshooting will result in a delay of the event. The DoY of leaf unfolding is finally calculated:

$\operatorname{DoY}_{\mathrm{LU}}=\mathrm{DoY}_{1, \mathrm{LU}}+c_{\mathrm{LU}}$

The approach for modeling the annual variability of the end of the growing season, is based on the findings of Estrella and Menzel (2006). A linear model is set up, utilizing averaged $T_{\text {mean }}$ of 2 seasonal periods ( DoY $_{0, \mathrm{LC}}-$ DoY $_{1, \mathrm{LC}}$, $\mathrm{DoY}_{2, \mathrm{LC}}-\mathrm{DoY}_{3, \mathrm{LC}}$ ) (1) late spring and (2) late summer-early autumn. Within these periods, a parabolic function assigns weight $\left(w_{\mathrm{LC}}\right)$ to the observed $T_{\text {mean }}$ :

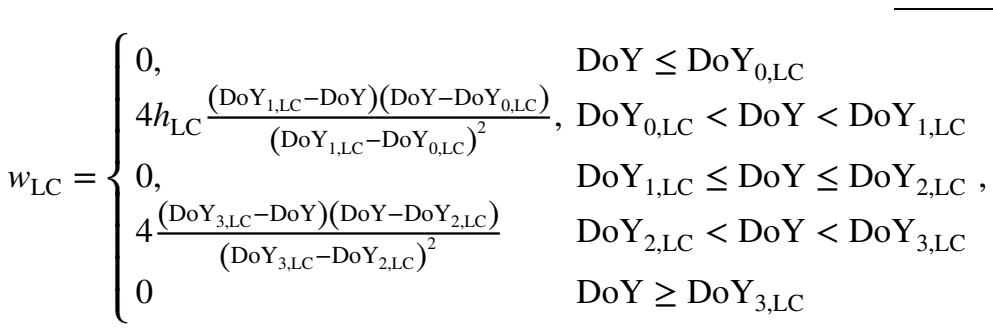

a graphical representation of the assessment of spring and autumn phenology:

$w A_{\mathrm{LC}}=\frac{\sum_{i=\mathrm{DoY}_{3 \mathrm{LC}}}^{\mathrm{DoY}_{0 \mathrm{LC}}} T_{\mathrm{mean}, i} w_{\mathrm{LC}, i}}{\sum_{i=\mathrm{DoY}_{3 \mathrm{LC}}}^{\mathrm{DoY}}\left|w_{\mathrm{LC}, i}\right|}$.

The annual DoY of LC is then calculated in a linear equation:

$\operatorname{DoY}_{\mathrm{LC}}=k_{\mathrm{LC}} w A_{\mathrm{LC}}+d_{\mathrm{LC}}$.

The functions to determine LU and LC were optimized, using a combination of simulated annealing (Kirkpatrick 1984) and the Gauss-Newton algorithm. Performance criterion was the Nash-Sutcliffe efficiency (NSE) (Nash and Sutcliffe 1970):

$\mathrm{NSE}=1-\frac{\sum_{i=1}^{n}\left(\mathrm{obs}_{i}-\mathrm{sim}_{i}\right)^{2}}{\sum_{i=1}^{n}\left(\mathrm{obs}_{i}-\overline{\mathrm{obs}}\right)^{2}}$.

To express the model error in days, the root mean squared error is also calculated:

$\operatorname{RMSE}=\left[n^{-1} \sum_{i=1}^{n}\left(\mathrm{obs}_{i}-\operatorname{sim}_{i}\right)^{2}\right]^{\frac{1}{2}}$.

\section{Water balance model}

An exhaustive description of the setup and the formulation of the WBM can be found in the supplementary!

\section{Model application}

The simulator was parameterized, using time-series of observed soil moisture. We used records of different depths to calculate a mean time-series, aiming to reflect the integrated volumetric soil moisture over soil depth $\left(z_{\mathrm{r}}\right)$.
Due to the fact that senescence dates correlate negatively with $T_{\text {mean }}$ in late spring, the parabolic function in the first period yields negative values, with a minimum of $h_{\mathrm{LC}}$. The weighted average $T_{\text {mean }}\left(w A_{\mathrm{LC}}\right)$ inside the temporal window is calculated. Figure $\mathrm{S} 2$ in the supplementary information states
Averages over a soil depth of $500 \mathrm{~mm}$ were calculated for all sites. Both canopy and the snowpack storage were initialized at $0 \mathrm{~mm}$. Soil water storage was initialized at the product of soil depth and the water content at field capacity $\left(z_{\mathrm{r}} \theta_{\mathrm{fc}}\right)$. The model ran a 200 day spin up, prior to the performance analysis timeframe. Twenty-six parameters 
(compare Table 3) were optimized by inverse modeling; a simulated annealing algorithm was applied. Performance criterion was the Nash-Sutcliffe efficiency (Eq. 12). The parameterization was performed over the entire investigation timeframe (Table 2).

\section{Water stress assessment}

The obtained parameterization was used to run the model over a reference climate period of 30 years. The timeframe was set from Jan 1983 to Dec 2012. Then, eight scenarios of climate warming were applied. Temperatures were increased from 0 to $4{ }^{\circ} \mathrm{C}$ in one degree steps. Four scenarios were run under the assumption that (1) phenology retains the values of the reference climate; four scenarios were run with (2) phenology responding to warmer conditions. This way, we wanted to quantify the influence of elongated growing seasons on the stands' water consumption and soil water deficit.

Different levels of water stress were calculated. The transpiration index $\left(T_{\mathrm{i}}\right)$ states the daily ratio between simulated actual transpiration and potential transpiration (transpiration which would occur under optimal root water supply) (Clausnitzer et al. 2011; Vilhar 2016). In our formulation, it corresponds to the water stress coefficient $\left(\mathrm{Kc}_{\mathrm{s}, \text { tree }}\right)$ in the calculation of the actual transpiration rate: $T_{\mathrm{i}}=\mathrm{Kc}_{\mathrm{s}, \text { tree }}$

A level of one corresponds to unlimited transpiration, a level of zero would correspond to a complete shutdown of transpiration. Investigating beech stands (Schwärzel et al. 2009) found indications of noteworthy water stress when $T_{\mathrm{i}}$ fell below $70 \%$. Therefore, we set the threshold for (at least) moderate soil water deficit to 0.7. According to Bréda et al. (2006), xylem embolism occurs when stomatal conductance drops below $10 \%$ of its initial value. Therefore, a second stress level was calculated: If $T_{\mathrm{i}}$ falls below 0.1 , we consider the stand affected by severe drought.

According to Granier et al. (1999), water stress occurs when the relative extractable water content (REW) drops below the critical value of 0.4 . REW is calculated by normalizing theta to the interval from the wilting point to field capacity. The formulation, which is presented here, allows soil moisture below the wilting point $\left(\theta_{\mathrm{pwp}}\right)$ and above field capacity $\left(\theta_{\mathrm{fc}}\right)$. Therefore, REW can take values below zero and above 1 !

$\mathrm{REW}=\frac{\theta-\theta_{\mathrm{pwp}}}{\theta_{\mathrm{fc}}-\theta_{\mathrm{pwp}}}$

Then, the number of days during the growing season with $T_{\mathrm{i}}$ or REW below the defined threshold was calculated. In this assessment, we considered the growing season as interval from the 25th of March $(\mathrm{DoY}=84)$ to the 11th of November $(\mathrm{DoY}=315)$. Years with more than 120 growing season days of $T_{\mathrm{i}}>0.7$ were defined as dry years. The threshold for drought years was reached with a minimum of 31 growing season days with $T_{\mathrm{i}}$ below 0.1 . At last, to gain information about the stands' photosynthetic activity, we estimated the gross primary production (GPP, $\mathrm{gm}^{-2} \mathrm{~d}^{-1}$ ) as the product of water-use efficiency (WUE) and the transpiration rate:

$\mathrm{GPP}=E_{\mathrm{C}} \mathrm{WUE}$

To estimate the WUE, we relied on an empirical relationship, which was proposed by Tang et al. (2006). The water-use efficiency was calculated as function of the vapor pressure deficit (VPD):

$\mathrm{WUE}=4.4+15.69 \mathrm{e}^{-5.94 \mathrm{VPD}}$.

\section{Results and discussion}

\section{Timing of phenological events}

Both, spring and autumn phenology showed high intraannual plasticity. Nevertheless, after transforming the data to an assembled time-series, LU revealed a distinct pattern, with a recent trend towards an earlier onset of the growing season (see Fig. 2a-d). On the contrary to very high intra-annual plasticity, the year to year variations of the winsorized means of LC were smaller compared to LU. The reason no trend towards a delaying of senescence was observed, might be found in the counteracting effect of late spring and late summer temperatures.

The parameterization of the LU module led to a good fit between observed and modeled onset of the growing season (compare Table 1; NSE $>0.89$, RMSE $<2$ days). A very low modeled $T_{0, \mathrm{LU}}\left(<-11^{\circ} \mathrm{C}\right)$ seems to be nonmeaningful in a plant physiological sense. On the other hand, the simulated effect of temperature forcing at cold conditions is partially nullified by low multiplier values from the day-length term, at the beginning of the forcing period, in early winter (see Fig. S5).

The regression approach, to predict the end of the growing season, utilizing the mean temperature of two temporal windows, was also suitable to reproduce the observed pattern to a sufficient degree (NSE $>0.73$, RMSE $<2$ days). The mechanism behind the acceleration of senescence by high temperatures in late spring was not elaborated in this work. Nevertheless, two explanatory assumptions are stated: High temperatures in spring point to an early onset of the growing season. This, and the high temperature itself might increase the water consumption, (1) inducing drought during critical phenological stages. (2) High temperatures in late spring might support the development of 

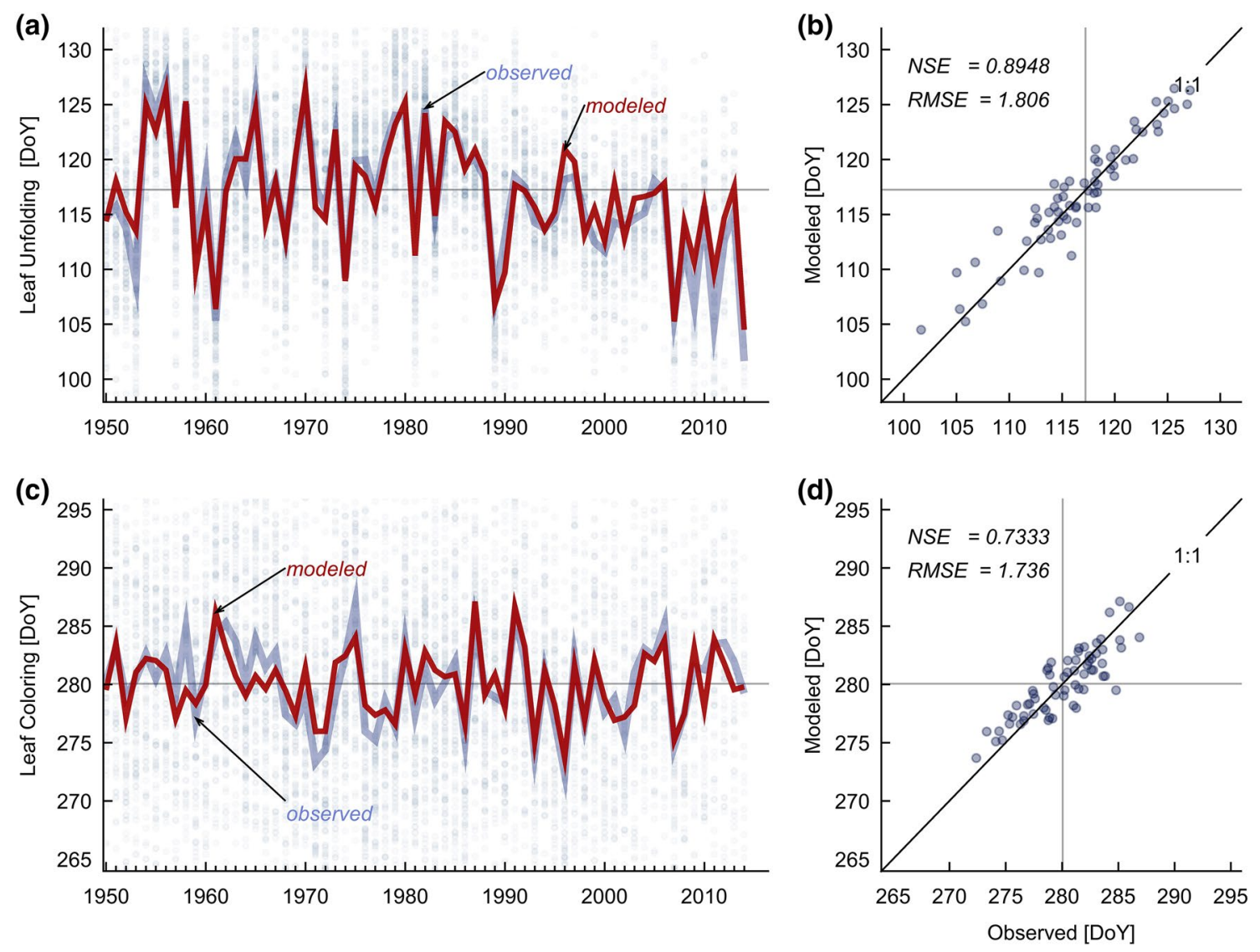

Fig. 2 a, c The model was fitted to an assembled time-series of annual DoYs (pale solid lines), which were calculated, if more than 10 annual observations (small dots) were available. Leaf unfolding and coloring data were processed analogously (a) where LU clearly shows a trend towards earlier onsets of the growing season in last decades, LC (c) reveals no such pattern. The reason for this might be

Table 1 Parameterization results of the phenological module

\begin{tabular}{llll}
\hline Leaf unfolding & \multicolumn{3}{l}{ Leaf coloring } \\
\hline DoY $_{0, \mathrm{LU}}$ & 4.353 & DoY $_{0, \mathrm{LC}}$ & 108.451 \\
$T_{0, \mathrm{LU}}$ & -10.820 & $\mathrm{DoY}_{1, \mathrm{LC}}$ & 167.207 \\
$T_{1, \mathrm{LU}}$ & 30.747 & $\mathrm{DoY}_{2, \mathrm{LC}}$ & 219.214 \\
$m_{\mathrm{LU}}$ & 0.362 & $\mathrm{DoY}_{3, \mathrm{LC}}$ & 286.441 \\
$x_{\mathrm{LU}}$ & 2.921 & $h_{\mathrm{LC}}$ & -0.618 \\
& & $k_{\mathrm{LC}}$ & 4.002 \\
& & $d_{\mathrm{LC}}$ & 261.107 \\
$n$ & 65 & $n$ & 65 \\
NSE & 0.895 & NSE & 0.733 \\
RMSE & 1.806 & RMSE & 1.736 \\
\hline
\end{tabular}

Optimization was conducted, using a combination of simulated annealing and the Gauss-Newton algorithm. Performance criterion was the Nash-Sutcliffe model efficiency found in the counteracting effect of late spring and late summer temperatures. b, d Observed assembled time-series mean of leaf unfolding and leaf coloring vs. the modeled timing of the event. Details about calculations of Nash-Sutcliffe efficiency (NSE) and root mean squared error (RSME in days) are given in the text

specific pest or pathogens, leading to stress induced, premature leaf coloring (see also Menzel et al. 2008).

\section{Water balance}

The approaches to describe fog precipitation, precipitation interception, as well as the responses of evapotranspiration and percolation to soil moisture, presented in this work are novel. Therefore, their parameterization cannot be relied on the literature data. Due to unavailability of direct measurements, they were deduced by model optimization, applying broad search ranges. In cases where literature values existed (e.g. degree day factors for snowmelt, field capacity), parameter values were searched in the close proximity of values stated in the literature. On both investigated sites, the optimization process lead to a good fit between the observed 
Table 2 The model calibration was conducted, utilizing soil moisture records of the entire model timeframe

\begin{tabular}{llllll}
\hline Site & Timeframe & $z(\mathrm{~cm})$ & $n$ & NSE & RMSE \\
\hline Kreisbach & $04 / 14 / 1999-02 / 10 / 2003$ & $00-50$ & 1294 & 0.9262 & 0.0132 \\
Klausen-Leopoldsdorf & $10 / 01 / 2006-09 / 30 / 2013$ & $00-50$ & 2262 & 0.9303 & 0.0163 \\
Exelberg & $10 / 01 / 2009-09 / 30 / 2012$ & $00-50$ & 33 & 0.9148 & 0.0152 \\
Jubiläumswarte & $10 / 01 / 2009-09 / 30 / 2012$ & $00-50$ & 33 & 0.9225 & 0.0176 \\
\hline
\end{tabular}

Optimization was performed, using a simulated annealing algorithm. Performance criterion was the NashSutcliffe Efficiency

$n$ number of utilized observations, NSE Nash-Sutcliffe Efficiency, RMSE root mean squared error $\left(\mathrm{LL}^{-1}\right)$

Table 3 Parameter optimization results for all 4 investigate sites

\begin{tabular}{|c|c|c|c|c|c|c|}
\hline Parameter & Description & Unit & $\mathrm{KB}$ & KL & EX & $\mathrm{JU}$ \\
\hline $\mathrm{rH}_{0}$ & Lower relative humidity threshold for fog precipitation & $\mathrm{rH}$ & 99.99 & 99.99 & 94.34 & 93.93 \\
\hline$f_{\mathrm{c}}$ & Fog coefficient & & 0 & 0 & 0.516 & 0.494 \\
\hline $\operatorname{DoY}_{\mathrm{CC}}$ & Canopy closure & DoY & 221.4 & 222.9 & 173.3 & 180.5 \\
\hline$l_{\mathrm{LC}}$ & Duration of leaf senescence & Days & 22.88 & 20.94 & 25.14 & 13.60 \\
\hline $\mathrm{ID}_{\text {LAI }}$ & Indeciduous fraction of leaf area at canopy closure & & 0.079 & 0 & 0 & 0 \\
\hline$C_{\text {max,LAI0 }}$ & Canopy interception capacity at $\mathrm{Kc}_{\mathrm{LAI}}=0$ & $\mathrm{~mm}$ & 2.221 & 0.632 & 0.325 & 0.309 \\
\hline$C_{\text {max,LAI1 }}$ & Canopy interception capacity at $\mathrm{Kc}_{\mathrm{LAI}}=1$ & $\mathrm{~mm}$ & 4.326 & 2.701 & 0.678 & 1.230 \\
\hline$K_{\mathrm{i}, \mathrm{LAI} 0}$ & Interception function shape parameter at $\mathrm{Kc}_{\mathrm{LAI}}=0$ & & 4.354 & 3.777 & 2.665 & 2.832 \\
\hline$K_{\mathrm{i}, \mathrm{LAI} 1}$ & Interception function shape parameter at $\mathrm{Kc}_{\mathrm{LAI}}=1$ & & 5.342 & 6.712 & 4.678 & 5.339 \\
\hline $\mathrm{Kc}_{\text {canopy }}$ & Crop coefficient for canopy evaporation & & 1.102 & 0.472 & 0.787 & 0.822 \\
\hline$\tau_{\mathrm{LAI} 0}$ & Maximum radiation transmittance coefficient at $\mathrm{Kc}_{\mathrm{LAI}}=0$ & & 0.742 & 0.701 & 0.802 & 0.805 \\
\hline$\tau_{\text {LAI1 }}$ & Minimum radiation transmittance coefficient at $\mathrm{Kc}_{\mathrm{LAI}}=1$ & & 0.390 & 0.321 & 0.319 & 0.291 \\
\hline$T_{\text {snow }}$ & Upper threshold temperature for snowfall & ${ }^{\circ} \mathrm{C}$ & 1.388 & 0.203 & 1.706 & 1.509 \\
\hline$T_{\text {melt }}$ & Lower threshold temperature for snowmelt & ${ }^{\circ} \mathrm{C}$ & 1.972 & 1.508 & 1.897 & 0.938 \\
\hline $\mathrm{DDF}_{\text {melt }}$ & Degree day factor for snowmelt & $\mathrm{mm}^{\circ} \mathrm{C}^{-1}$ day $^{-1}$ & 2.165 & 2.982 & 0.813 & 0.686 \\
\hline$f_{\text {by }}$ & Water fraction, bypassing the soil box & & 0.362 & 0.083 & 0.437 & 0.112 \\
\hline$k_{\text {sat }}$ & Saturated conductivity & $\mathrm{LL}^{-1}$ day $^{-1}$ & 0.071 & 0.038 & 0.017 & 0.021 \\
\hline$\theta_{\mathrm{m}}$ & Shape parameter for percolation response & & 0.528 & 0.728 & 0.753 & 0.748 \\
\hline$\theta_{\text {sat }}$ & Saturated water content & $\mathrm{LL}^{-1}$ & 0.502 & 0.520 & 0.369 & 0.420 \\
\hline$\theta_{\mathrm{fc}}$ & Field capacity & $\mathrm{LL}^{-1}$ & 0.344 & 0.392 & 0.285 & 0.362 \\
\hline$\theta^{*}$ & Upper threshold water content for evapotranspiration limit. & $\mathrm{LL}^{-1}$ & 0.344 & 0.410 & 0.270 & 0.348 \\
\hline$\theta_{\text {pwp }}$ & Permanent wilting point, lower threshold for transpiration & $\mathrm{LL}^{-1}$ & 0.189 & 0.228 & 0.085 & 0.155 \\
\hline$\theta_{\text {res }}$ & Residual water content, lower threshold for soil evaporation & $\mathrm{LL}^{-1}$ & 0.008 & 0.003 & 0.012 & 0.003 \\
\hline $\mathrm{ET}_{\mathrm{m}}$ & Shape parameter for evapotranspiration response & & 0.488 & 0.391 & 0.422 & 0.424 \\
\hline $\mathrm{Kc}_{\text {tree }}$ & Crop coefficient for vegetation at canopy closure & & 1.361 & 1.783 & 0.526 & 0.857 \\
\hline $\mathrm{Kc}_{\text {ground }}$ & Crop coefficient for soil evaporation & & 0.364 & 0.517 & 0.209 & 0.398 \\
\hline
\end{tabular}

and predicted soil water content (NSE $<0.92 .5)$; the simulator was capable to track the temporal dynamics of the daily average soil moisture $\left(\theta, \mathrm{L} \mathrm{L}^{-1}\right)$, over the whole investigation timeframe (Fig. S6) (Table 2).

In the following section, the parameterization of the WBM is discussed. For the parameter configuration of all 4 sites, see Table 3 . On the sites KR and KL, the fog precipitation module had no improving effect on the models' performance. In both cases, the optimization process led to fog coefficient $\left(f_{c}\right)$ values close to zero (see Table 3 ). The amount, fog is contributing to the total precipitation, seems insignificant at these locations. An explanation might be found in the sites relief; both investigated stands are located at lower hill slopes, partially shielded from (at least) two directions. A different picture was found on the EX and JU site; they are both located at upper hill slopes, close to the hill top, leaving them much more exposed to direct air flow.

The optimization process lead to relatively high parameters values, describing the maximum capacity of canopy storage $\left(C_{\max }\right)$. For a central European beech stand, Gerrits et al. (2010) reported a canopy $C_{\max }$ ranging from $0.4 \mathrm{~mm}$ for winter conditions to $0.9 \mathrm{~mm}$ in summer. In this work, 
Table 4 Breakdown of modeled export fluxes, given as mean annual sums and in percent of the observed precipitation

\begin{tabular}{|c|c|c|c|c|c|c|c|c|}
\hline \multirow{3}{*}{$\begin{array}{l}\text { Site } \\
n \text { (years) } \\
\text { Unit }\end{array}$} & \multicolumn{2}{|c|}{ Kreisbach } & \multicolumn{2}{|c|}{ Klausen-Leo. } & \multicolumn{2}{|c|}{ Exelberg } & \multicolumn{2}{|c|}{ Jubiläumswarte } \\
\hline & 30 & & 30 & & 30 & & 30 & \\
\hline & $\mathrm{mm} \mathrm{a}^{-1}$ & $\%$ & $\mathrm{~mm} \mathrm{a}^{-1}$ & $\%$ & $\mathrm{~mm} \mathrm{a}^{-1}$ & $\%$ & $\mathrm{~mm} \mathrm{a}^{-1}$ & $\%$ \\
\hline Precipitation $(+$ fog $)$ & 961.0 & 100 & 831.1 & 100 & 751.5 & 100 & 654.5 & 100 \\
\hline Fog & 0 & 0 & 0 & 0 & 6.0 & 0.8 & 6.8 & 1.1 \\
\hline Canopy evaporation & 202.8 & 21.7 & 88.4 & 10.8 & 54.4 & 7.4 & 68.4 & 10.7 \\
\hline Infiltration & 480.8 & 49.7 & 656.4 & 79.1 & 386.1 & 51.5 & 492.4 & 75.7 \\
\hline Soil evaporation & 106.6 & 11.6 & 127.1 & 15.6 & 100.1 & 13.8 & 189.0 & 30.1 \\
\hline Transpiration & 189.1 & 19.8 & 246.3 & 29.8 & 174.4 & 23.5 & 180.9 & 27.6 \\
\hline Bypass flow & 277.6 & 28.6 & 85.5 & 10 & 311.1 & 41.4 & 93.9 & 13.9 \\
\hline Percolation & 185.1 & 18.4 & 283.0 & 33.7 & 111.8 & 14.6 & 122.9 & 18.6 \\
\hline
\end{tabular}

the parameterization led to a maximum storage capacity of 4.3 and $2.7 \mathrm{~mm}$ for the $\mathrm{KB}$ and the KL site, respectively. For the beech stand mentioned above, Gerrits et al. (2010) calculated a litter layer storage capacity with a yearly average of $1.8 \mathrm{~mm}$, temporally peaking in autumn $(2.8 \mathrm{~mm})$. So it seems possible, that high $C_{\max }$ might be explained by the contribution of the litter layer to precipitation interception. Soil moisture records, utilized in the calibration process, existed for a minimum depth of $10 \mathrm{~cm}$ and $15 \mathrm{~cm}$, for Kreisbach and Klausen-Leopoldsdorf, respectively. It seems also plausible that the canopy interception module accounts for soil water storage/interception, caused by the topmost layer of the mineral soil. An alternative to explain high values for $C_{\max }$ arises from the assessment of precipitation on a daily time-step: The possibility of multiple storms during 1 day is neglected. In such a case, our formulation might underestimate canopy storage (compare Pearce and Rowe 1981). Here, high values for $C_{\max }$ would have a compensating effect. High values for the coefficient, scaling the reference evapotranspiration $\left(\mathrm{ET}_{\mathrm{O}}\right)$ to canopy evaporation ( $\left.\mathrm{Kc}_{\text {canopy }}\right)$, could be explained by the low surface resistance of the wet canopy (Herbst et al. 2008). The combination of high $\mathrm{Kc}_{\text {canopy }}$ and high $C_{\max }$ values is leading to high interception evaporation $\left(E_{\mathrm{I}}\right)$ fluxes. On the KB site, deposition chemistry was monitored from the beginning of May 2002 to the end of October 2003 (Berger et al. 2008). In this course, also canopy evaporation fluxes were estimated as the difference between observed open area precipitation and the sum of throughfall and stemflow. A determined annual interception sum of $238 \mathrm{~mm}(26 \%$ of the open area precipitation) is in close resemblance to the estimate of the mean annual interception, presented in this work. On the KL site, throughfall was monitored in a bi-weekly interval from 2006 to 2010 . For dormant and growing season, $5.8 \%$ and $11.9 \%$, of the observed precipitation was intercepted by the canopy, respectively. For the same temporal interval, the simulation delivered canopy evaporation percentages of 8 and 11.9 for the dormant and growing season, respectively. For different beech stands, Peck and Mayer (1996) reported rainfall interception ranging from 5 to $48 \%$ of total precipitation, with a mean of $20 \%$. On our investigated sites, modeled annual rainfall interception (canopy evaporation), was found on the low end of these estimates. Precipitation interception decreased from west to east, reaching its lowest value on the EX site (Table 4).

The calibration process lead to an unremarkable parameterization of the module, describing snow accumulation and snowmelt. Threshold temperatures for snowfall and snowmelt, as well as the degree day factors for snowmelt, were in the range of literature values. For a summary on threshold temperatures for snowfall, see Feiccabrino and Lundberg (2008), a summary on snowmelt degree-day factors for various catchments is given by Hock (2003).

On the KR forest location, an assessment of physical soil characteristics revealed a pore volume $52 \%$, and a volumetric water content of $18.85 \%$ at $1 \mathrm{MPa}$ (Schume et al. 2004). The parameterization for this site delivered values for saturation water content $\left(\theta_{\text {sat }}\right)$ and $\theta_{\text {pwp }}$, which are located in the close vicinity of the measured ones.

For different beech stands, Peck and Mayer (1996) reported annual transpiration $\left(E_{\mathrm{C}}\right)$ sums ranging from 268 to 601 with a mean of $363 \mathrm{~mm}$. Our estimations of annual $E_{\mathrm{C}}$ were below these values, on all sites (Table 4). Especially on the KR and KL plot, is seems possible that transpiration water fluxes were slightly underestimated in the simulation outcome (Table 4). On the KR plot, beech roots were found at a soil depth of $85 \mathrm{~cm}$ (Schmid 2002). On the KL plot, an assessment of the sites soil characteristics revealed medium to strong root penetration down to $65 \mathrm{~cm}$ soil depth (Neumann et al. 2001). Due to reasons of soil moisture data availability, only the topmost $50 \mathrm{~cm}$ of the mineral soil were considered in this work, neglecting the possible contribution of deeper soil layers to the trees' water supply.

On the KR and especially on the EX plot, the simulator delivered high relative fractions of bypass flow (Table 4). 


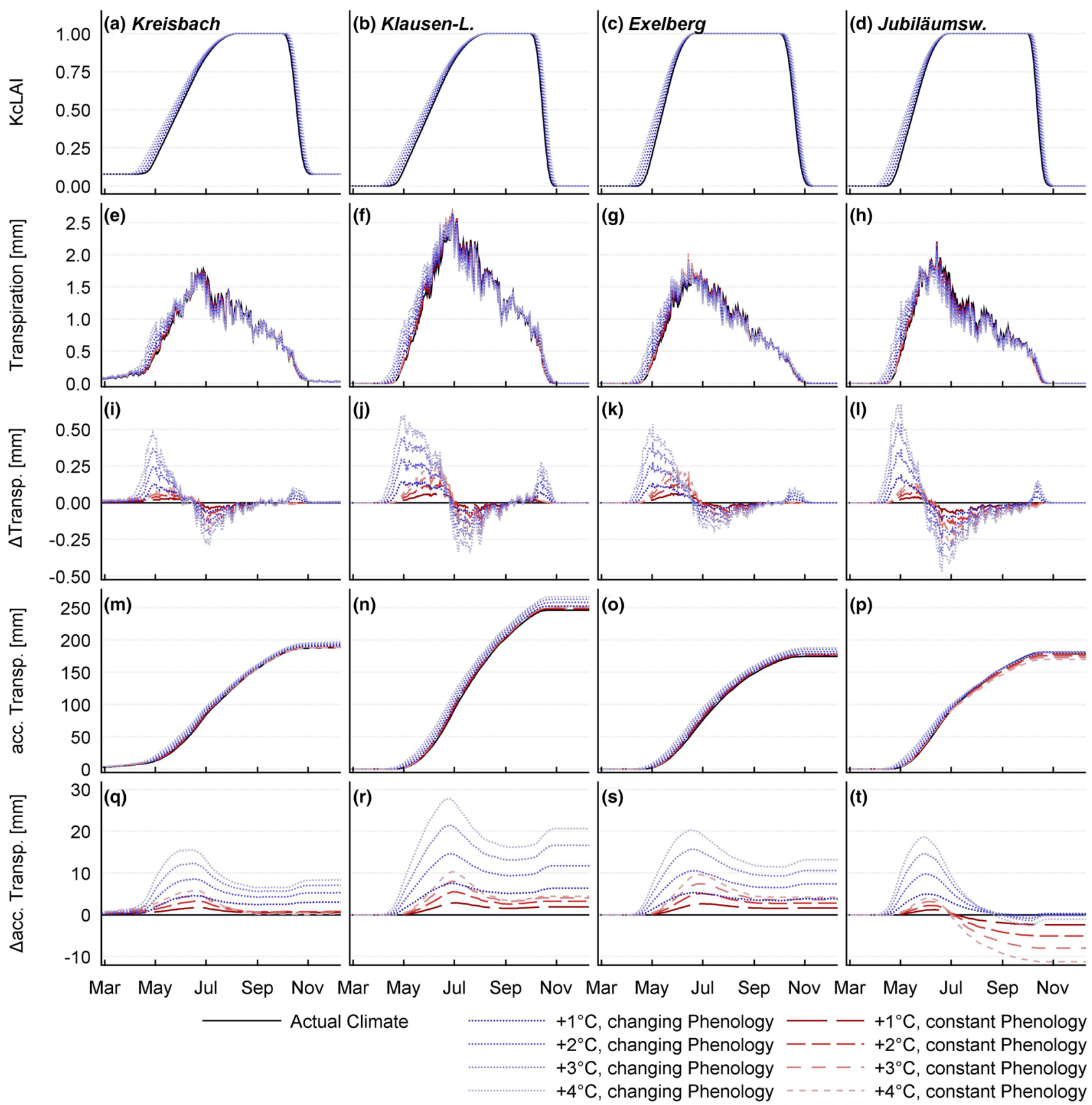

Fig. 3 Result of the temperature sensitivity analysis on day of year base. a-d Relative leaf area: One degree temperature rise corresponds roughly to an increase of 4.5 days in growing season length, whereat LU is affected more strongly than LC. e-h Mean daily transpiration for all 4 sites: Transpiration is modeled highest at the beginning of summer. The KL site experiences the highest transpiration rates. i-l Change of daily transpiration compared to the actual climate: The increase of transpiration at the beginning of the growing sea-

Analogue to the underestimation of $E_{\mathrm{C}}$ fluxes, the disregarding of the influence of deeper soil layers on the stands' water balance might result in an overestimation of bypass flow. son caused by higher temperatures and earlier LU is followed by a marked decrease in summer, due to soil water depletion. $\mathbf{m}-\mathbf{p}$ Accumulated transpiration: The KL site displays the highest annual sums. q-t Change of the accumulated transpiration compared to the present climate. Without consideration of elongated growing seasons, the JU site responds with a decline of transpiration due to soil drought in mid-summer. This decline is compensated by the effect of the elongated growing seasons

High transpiration rates during the growing season, in contrast to low evaporative water consumption during the leafless period of the year, are leading to a distinct seasonal pattern of soil moisture. Where in the growing season, $\theta$ 
above field capacity occurs only exceptional, in the cold part of the year field capacity is rarely undershot, determining percolation through the soil profile as phenomenon of the dormant season (Fig. S7c,d).

\section{Climate change assessment}

Step-wisely increased temperatures led to a proportional elongation of the growing season. One ${ }^{\circ} \mathrm{C}$ roughly corresponded to an elongation of 4.7 days. The modeled relationship between warming and lengthening of the growing season was almost linear. All sites responded with a similar pattern (Fig. 3a-d). Spring phenology showed stronger reaction than autumn phenology. One ${ }^{\circ} \mathrm{C}$ warming corresponds to leaf unfolding, 3.5 days earlier. Regarding leaf senescence, the delaying effect of warmer late-summer temperatures was not fully compensated by the accelerating effect of high late-spring temperatures. A temperature increase of $1{ }^{\circ} \mathrm{C}$ corresponded to a delay of LC of 1.2 days.

The simulated temperature rise had a strong effect on the stands' water balance. Apparently, higher temperatures during the growing season led to drier soils (Fig. 4a-d). Gaseous water exports increased, while liquid exports decreased. Overall, the soil evaporation partition was affected positively, the percolation water fraction was affected negatively by warmer conditions (Fig. 5a-d). Increased ET was shifting soil moisture to lower levels, favoring the evaporation partition of ET, which is capable to deplete soil water at moisture levels below the wilting point, inducing severe drought.

Under current conditions, the KR and JU site experience frequent dry and drought years (Fig. 5i,l). Here, rising temperatures might lead to a drastic exacerbation of the situation. The reason, that the KR site (which is receiving the highest amount of precipitation) shows a similar behavior as the JU site (which is receiving the lowest annual precipitation sums), can be found in an unfavorable combination of high canopy evaporation rates with high bypass water fluxes (Table 4). At the end, only a small partition of the incoming water is available for plant consumption.

Under current conditions, drought is a rare phenomenon on the KL and EX site (Fig. 5f, g): The KL stand receives relatively high annual precipitation sums. Only a small percentage is lost by interception (Table 4). Paired with a high infiltration capacity, this has a beneficial effect on the stands' water supply. But also here, rising temperatures led to an increase of dry and drought years. Due to the favorable current state, the impact seemed to be less pronounced. It appears paradox, that the driest site experiences the lowest risk for severe soil drought, but the EX forest benefits from a very low modeled wilting point (see Table 3 ). This is enabling plant water supply at low soil moisture levels (Fig. S8). On this site, severe soil drought does only occur infrequently under present conditions and also rising temperatures lead to no significant increase of the drought risk (Fig. $4 \mathrm{~s}, \mathrm{w}$ ).

An earlier start of the growing season let to higher $E_{\mathrm{C}}$ water fluxes from spring to early summer (Fig. 3i-1). The effect was amplified by high rates of potential evapotranspiration during this period. Early LU had an intensifying effect on soil water stress in summer. As a consequence, the scenarios which considered changes in spring phenology experienced a drastic transpiration drop in mid-summer. On the contrary to soil water stress, extended growing seasons had almost no effect on the frequency and duration of severe drought. On all sites, there was a high probability for moderate soil water deficit $\left(T_{\mathrm{i}}<07\right)$ during the entire growing season, with a weakly pronounced maximum at the beginning of summer. On the other hand, the risk for severe drought $\left(T_{\mathrm{i}}<0.1\right)$ shows a very distinct peak at the end of August (Fig. 4q-t).

Longer growing seasons are assumed to widen the timeframe for potential C-assimilation (Gunderson et al. 2012; Vitasse et al. 2009). Without consideration of the growing season elongation caused by higher temperatures, all sites responded with decreased annual GPP due to water stress in mid-summer (Fig. 6e-h). In our simulation, prolonged growing seasons led to a marked increase of productivity at early stages of the growing season, followed by a significant depression from July to September (compare also Bergh et al. 2003). Growing season elongations were hardly sufficient to compensate for the productivity drop in mid-summer, caused by soil water stress. Only the EX site exhibits a net gain of GPP due to the combination of higher temperatures and longer growing seasons (Fig. 6o).

Falling in a time of high potential productivity, the extension at the start of the growing season had a stronger effect than the delay of autumn senescence (compare Gunderson et al. 2012).

\section{Conclusion}

In this work, a simulator is presented, aiming to depict the water fluxes and the phenological dynamics of beech forest stands. Covering forest sites dominated by deciduous trees, the formulation comprises routines for the inter- and intra-annual dynamics of the vegetation cover. A routine is introduced, calculating fog precipitation as a function of air temperature, relative humidity and wind speed. Furthermore, precipitation interception is calculated, utilizing a function based on the Langmuir isotherm. Soil processes (saturation excess overflow, percolation, soil evaporation, and transpiration) are described, utilizing a zero dimensional box model approach. Despite the strong simplification of the plant-soil system, this approach was sufficient to provide an accurate 


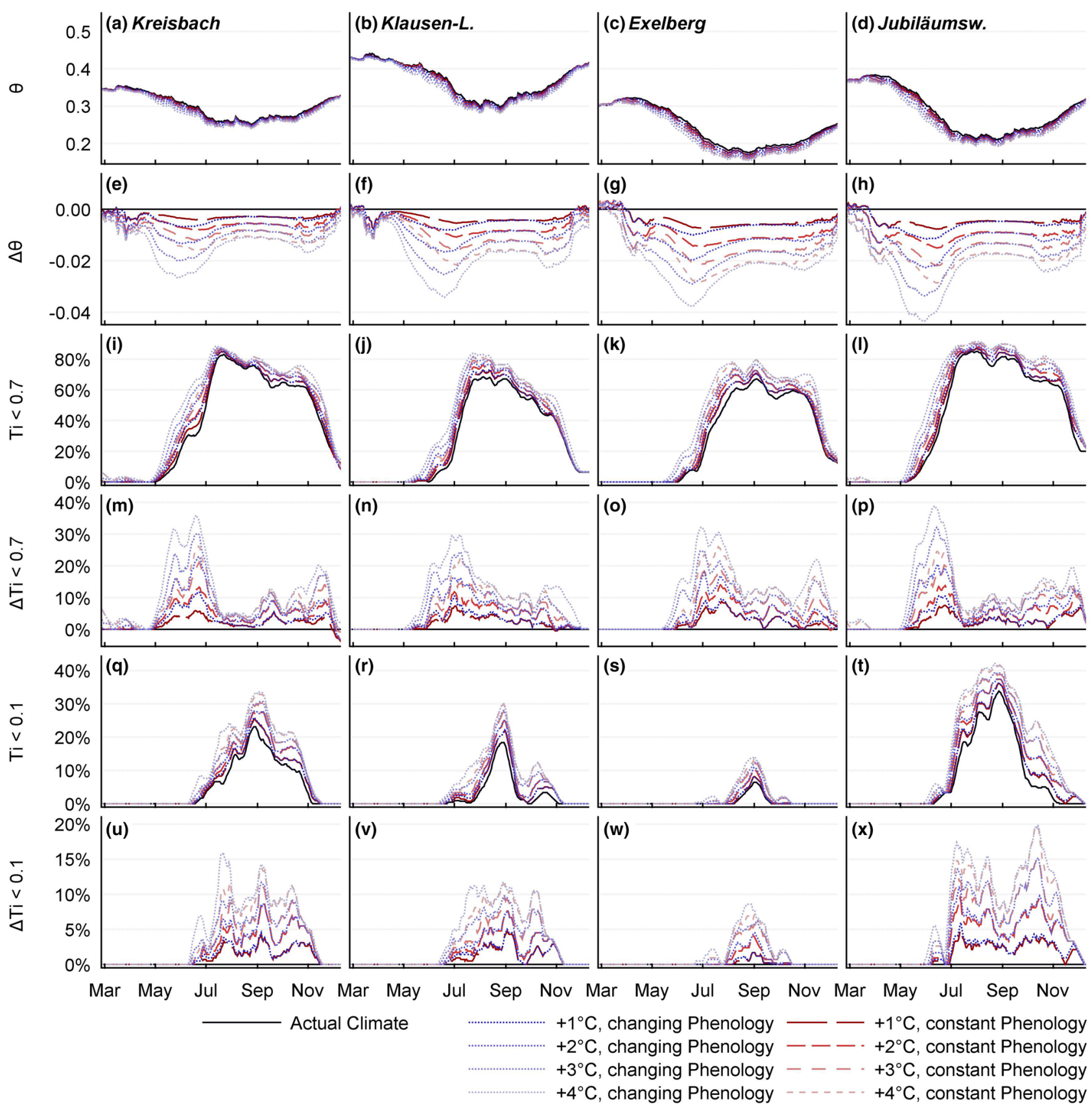

Fig. 4 Result of the temperature sensitivity analysis on day of year base. a-d Seasonal course of the relative water content: All sites display the same seasonal dynamics with lowest soil moisture during the growing season. The EX site appears to be strikingly drier than the other sites. $\mathbf{e}-\mathbf{h}$ Changes of soil moisture compared to the present climate: All investigated forest stands are apparently getting drier. The KB and KL site seem to be affected slightly weaker than the other sites. The reduction of soil moisture is most pronounced at the beginning of summer, also amplified by an earlier LU. i-l Probability of water stress (defined as $T_{\mathrm{i}}<0.7$ ): On all sites, water stress is the usual soil state during the warm season. The highest probability is found in mid-summer. $\mathbf{m}-\mathbf{p}$ Change of the water stress probability, compared to the present state. Warmer temperatures e.g. longer growing seasons increase the risk of soil water stress, especially in early summer. An earlier LU amplifies the probability of water stress, especially at the beginning of summer. q-t Risk of severe soil drought (defined as $T_{\mathrm{i}}<0.1$ ): All sites show the highest probability of severe drought at the end of August. Although the EX site appears to be the driest site, the risk for severe water stress is strikingly low. The reason can be found in the low wilting point (see Table 3, Fig. S8), allowing transpirative water consumption at low soil moisture. $\mathbf{u}-\mathbf{x}$ Change of drought risk, compared to present conditions: Higher temperatures increase the risk of severe drought on all sites. The KB and JU site show the highest vulnerability. On these sites, a temperature rise of $4{ }^{\circ} \mathrm{C}$ more than doubles the probability for severe drought. On the other hand, the elongation of the growing season has almost no impact on the drought risk. The driest site (EX) exhibits the weakest increase in the risk of severe drought 


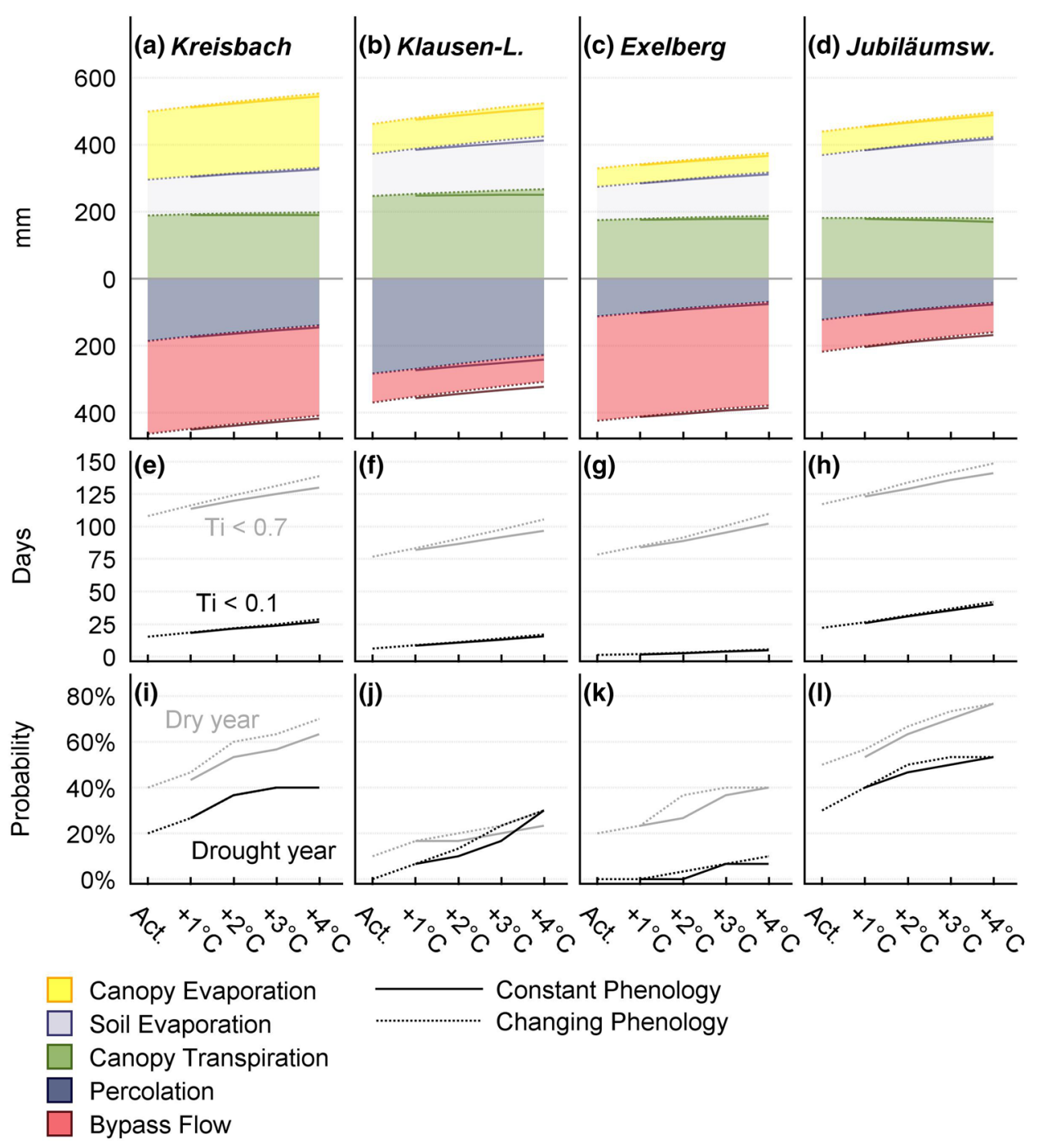

Fig. 5 a-d The influence of rising temperatures on the stands' annual export flux sums. Liquid and gaseous fluxes are displayed below and above zero, respectively. Warmer temperatures decrease the fraction of percolation, while (unproductive) soil evaporation rises. Although potential evapotranspiration rises, annual transpiration shows almost no response to higher temperature. The reason for this can be found in drier soils, which are favoring soil evaporation. $\mathbf{e}-\mathbf{h}$ Days with water stress (defined as $T_{\mathrm{i}}<0.7$ : grey line) and soil drought $\left(T_{\mathrm{i}}<0.1\right.$ : black line) within the growing season (from 25th March to 11th November): All sites display a distinct increase of dry days per year, with rising temperature. Except on the EX site, higher temperatures lead also to an increased frequency of drought days per year. In both cases, the effect of elongated growing seasons is almost negligible.

prediction of the vertically integrated soil moisture on both investigated plots. The formulation, which's set up is exhibited in this article and the supplementary, it then used to assess changes in the water balance, caused by increasing temperatures.

Climate change might affect Central European forests in multiple ways. Along with the rise in temperature, the i-l We define dry years as years with more than 120 days of $T_{\mathrm{i}}<0.7$ during the growing season; drought years are defined as years with more than 30 days of $T_{\mathrm{i}}<0.1$ during the growing season. Under current climate the risk for drought years does not exceed $20 \%$, meaning drought years occur roughly every 5 th year. On the KL and EX site, no year fulfilled the criteria for drought years, within the reference climate period. On the EX site, $4{ }^{\circ} \mathrm{C}$ warming lead also to no noteworthy increase of drought years. Under current conditions, the $\mathrm{KB}$ and JU site are facing the highest risk of severe soil water deficit. Considering an exacerbation due to rising temperatures, it seems possible that these stands might undergo future changes in species composition and productivity

sites will face the effects of changing precipitation patterns, rising atmospheric $\mathrm{CO}_{2}$ concentration, and the change of frequency, duration and intensity of extreme weather events. On the biotic side, the increased occurrence of pathogens will put even more pressure on forest ecosystems. In this work, we focused solely on the effect of rising temperatures 


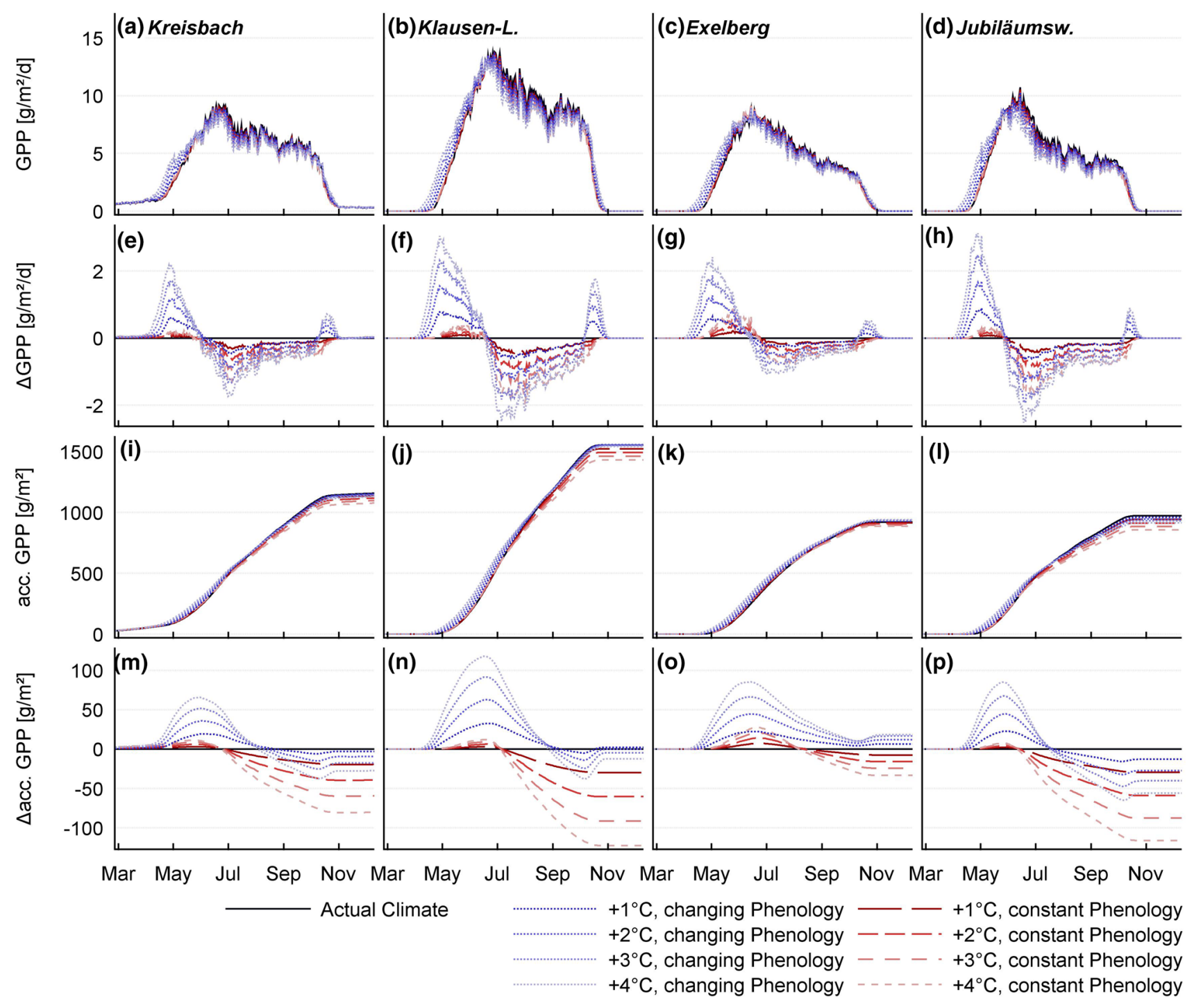

Fig. 6 Gross primary production on a day of year base: GPP was calculated as the product of transpiration water fluxes and the estimated water use efficiency. a-d GPP shows a pattern, very similar to transpiration. $\mathbf{e}-\mathbf{h}$ Change of daily GPP compared to the reference scenario: Higher temperatures in spring and earlier LU accelerate the assimilation early in the season, before soil moisture deficit hampers primary production in mid-summer. $\mathbf{i}-\mathbf{l}$ Accumulated GPP over the year: analogue to annual transpiration, the KL plot $\mathbf{j}$ shows the highest productivity. $\mathbf{m}-\mathbf{p}$ Change of the accumulated primary pro-

of the stands' water balance. The result of the simulation leads to the suggestion of mitigating measures.

To decrease the impact of drought on the forest stand, Bolte et al. (2007) point out the importance of a deliberate water resource management. They claim, that reduction in the shelterwood (1) decreases the overall water consumption of the stand and the (2) drought risk of overtopped trees. Our modeling work points out the opposite: A reduction of leaf area might lead to reduced water consumption by stand transpiration. On the other hand, unproductive soil evaporation duction to the reference climate period: All warming scenarios show an advance in production in late spring, which dissipates in summer. Without consideration of a change in the growing season length, all warming scenarios respond with decreased annual assimilation. Due to a compensating effect of elongated growing seasons, rising temperatures lead to no net change of the stands' annual primal production. Again, the EX stand represents an exception. It appears paradox that the driest site seems to be also the only site, which might benefit from higher temperatures!

is promoted by the increased aeration and light availability at the forest ground. At soil moisture approaching the wilting point, trees respond by actively shutting down transpiration. Only soil evaporation is capable to cause a noteworthy soil water depletion at soil moisture levels close to the wilting point, inducing severe drought. A dense canopy cover might help to counteract this, by suppressing evaporative fluxes from the soil. In that context, the strict differentiation between moderate soil water deficit and severe soil drought seems reasonable. Soil water deficit during the growing 
season seems to be a very common state on the investigated sites. It is clearly represented through our simulations that trees decrease their productivity during periods of water stress, but overall, they seem sufficiently adapted to such conditions. Only a strong increase in the frequency of moderate soil water stress might induce a shift in the composition towards species, with higher tolerance to soil water deficit. Severe drought on the other hand, might actively lead to severe damage of the stand (compare Barigah et al. 2013), resulting in more abrupt, or even catastrophic, changes in the appearance of the forest.

Acknowledgements Open access funding provided by Austrian Science Fund (FWF). This research was funded by the Austrian Science Fund (FWF, Project number P23861-B16, granted to TW Berger) and the Commission for Interdisciplinary Ecological Studies (KIÖS) at the Austrian Academy of Sciences (Project number 2010-05, granted to TW Berger). For her active support during the field campaign, we thank Pétra Berger. Level II data from Klausen-Leopoldsdorf was provided by the Austrian Research Centre for Forests. For the provision of meteorological and soil data from the Kreisbach site, which were generated within the framework of the Special Research Program 'Forest Ecosystem Restoration' (SFB 008), we thank Helmut Schume. For the possibility to access air temperature data, the providers in the ECA\&D project are acknowledged. For the provision of temperature and precipitation records, we thank the operator of a private weather station, Thomas Huber. Al last, we thank the ZAMG and the Austrian Hydrographic Service (eHYD) for the provision of meteorological data, which was used for gap filling purposes.

Open Access This article is distributed under the terms of the Creative Commons Attribution 4.0 International License (http://creativeco mmons.org/licenses/by/4.0/), which permits unrestricted use, distribution, and reproduction in any medium, provided you give appropriate credit to the original author(s) and the source, provide a link to the Creative Commons license, and indicate if changes were made.

\section{Appendix}

To achieve sigmoid shape transitions of a variables $(x)$ response $(y)$ inside a window ( $x_{0}$ to $x_{1}$ ), the 'smoothstep function' (compare Dolschak et al. 2015) was applied in several cases. $y_{0}$ and $y_{1}$ state left and right threshold responses, respectively. The variable $x$ has to be normalized into an auxiliary variable $(t)$ inside the interval $0-1$ :

$t=\frac{x-x_{0}}{x_{1}-x_{0}}$.

The transition is described using a third order polynomial:

$y= \begin{cases}y_{0}, & x \leq x_{0} \\ y_{0}+\left(y_{1}-y_{0}\right)\left(3 t^{2}-2 t^{3}\right), & x_{0}<x<x_{1} . \\ y_{1}, & x \geq x_{1}\end{cases}$ $y=\operatorname{smooth}\left(x, x_{0}, x_{1}, y_{0}, y_{1}\right)$.

To alter the shape of the transition, the latter function was modified, by introducing an exponent term:

$y= \begin{cases}y_{0}, & x \leq x_{0} \\ y_{0}+\left(y_{1}-y_{0}\right)\left(3 t^{2}-2 t^{3}\right)^{\ln 0.5 / \ln m}, & x_{0}<x<x_{1} . \\ y_{1}, & x \geq x_{1}\end{cases}$

The parameter $m$ states the relative $x$ position between $x_{0}$ and $x_{1}$ where the response $(y)$ reaches $50 \%$ of the transition from $y_{0}$ to $y_{1}$. In the article the 'modified smoothstep function' is stated as:

$y=\operatorname{msmooth}\left(x, x_{0}, x_{1}, y_{0}, y_{1}, m\right)$.

The description of the air temperature dependent forcing of spring phenology uses a combination of a second and first order polynomial. The variable, which is being transformed, has to be normalized to the interval $x_{0}$ to $x_{1}$, using Eq. 18 .

$y=y_{0}+\left(y_{1}-y_{0}\right) \begin{cases}0, & x \leq x_{0} \\ t, & x_{0}<x<x_{1} \\ 2 t-1, & x \geq x_{1}\end{cases}$

In the paper, the function, which is optically resembling the shape of a hockey stick, is stated as:

$y=\operatorname{hockey}\left(x, x_{0}, x_{1}, y_{0}, y_{1}\right)$.

We calculate precipitation interception using a function, based on the Langmuir sorption isotherm. I states interception, $C_{\max }$ the maximum charge of the canopy, $K_{\mathrm{i}}$ the shape parameter and $T$ throughfall:

$I=\frac{K_{\mathrm{i}} C_{\max } T}{1+K_{\mathrm{i}} T}$.

Substituting Interception with the difference of precipitation $(R)$ and throughfall yields:

$R-T=\frac{K_{\mathrm{i}} C_{\max } T}{1+K_{\mathrm{i}} T}$.

Avoiding the intricacies of an implicit formulation, we solve the equation for throughfall:

$T=\frac{\sqrt{K_{\mathrm{i}}^{2}\left(C_{\max }-R\right)^{2}+2 K_{\mathrm{i}}\left(C_{\max }+R\right)+1}+K_{\mathrm{i}}\left(R-C_{\max }\right)-1}{2 K_{\mathrm{i}}}$.

In the article this 3-argument function is stated as:

$T=\operatorname{tru}\left(R, C_{\max }, K_{\mathrm{i}}\right)$.

In the article the smoothstep function is stated as: 


\section{References}

Barigah TS et al (2013) Water stress-induced xylem hydraulic failure is a causal factor of tree mortality in beech and poplar. Ann Bot Lond 112:1431-1437

Basler D, Körner C (2012) Photoperiod sensitivity of bud burst in 14 temperate forest tree species. Agric Forest Meteorol 165:73-81. https://doi.org/10.1016/j.agrformet.2012.06.001

Berger TW, Untersteiner H, Schume H, Jost G (2008) Throughfall fluxes in a secondary spruce (Picea abies), a beech (Fagus sylvatica) and a mixed spruce-beech stand. Forest Ecol Manag 255:605-618

Bergh J et al (2003) Modelling the short-term effects of climate change on the productivity of selected tree species in Nordic countries. Forest Ecol Manag 183:327-340

Blümel K, Chmielewski FM (2012) Shortcomings of classical phenological forcing models and a way to overcome them. Agric Forest Meteorol 164:10-19. https://doi.org/10.1016/j.agrfo rmet.2012.05.001

Bohn U, Gollub G, Hettwer C, Neuhäuslova Z, Raus T, Schlüter H, Weber H (2004) Map of the natural vegetation of Europe. Federal Agency for Nature Conservation, Bonn

Bolte A et al (2009) Adaptive forest management in central Europe: climate change impacts, strategies and integrative concept. Scand J Forest Res 24:473-482

Bolte A, Czajkowski T, Kompa T (2007) The north-eastern distribution range of European beech-a review. Forestry 80:413-429

Bréda N, Huc R, Granier A, Dreyer E (2006) Temperate forest trees and stands under severe drought: a review of ecophysiological responses, adaptation processes and long-term consequences. Ann Forest Sci 63:625-644

Caffarra A, Donnelly A (2011) The ecological significance of phenology in four different tree species: effects of light and temperature on bud burst. Int J Biometeorol 55:711-721. https://doi. org/10.1007/s00484-010-0386-1

Cannell M, Smith R (1983) Thermal time, chill days and prediction of budburst in Picea sitchensis. J Appl Ecol 1:951-963

Capdevielle-Vargas R, Estrella N, Menzel A (2015) Multiple-year assessment of phenological plasticity within a beech (Fagus sylvatica L.) stand in southern Germany. Agric Forest Meteorol 211:13-22

Ciais $\mathrm{P}$ et al (2005) Europe-wide reduction in primary productivity caused by the heat and drought in 2003. Nature 437:529-533

Clausnitzer F, Köstner B, Schwärzel K, Bernhofer C (2011) Relationships between canopy transpiration, atmospheric conditions and soil water availability - analyses of long-term sap-flow measurements in an old Norway spruce forest at the Ore Mountains/Germany. Agric Forest Meteorol 151:1023-1034

Dittmar C, Zech W, Elling W (2003) Growth variations of common beech (Fagus sylvatica L.) under different climatic and environmental conditions in Europe-a dendroecological study. Forest Ecol Manag 173:63-78

Dolschak K, Gartner K, Berger TW (2015) A new approach to predict soil temperature under vegetated surfaces. Model Earth Syst Environ 1:1-14. https://doi.org/10.1007/s40808-015-0041-2

EEA (2015) Global and European temperatures. http://www.eea.europ a.eu/data-and-maps/indicators/global-and-european-temperatur e-1/assessment. Accessed 06 Feb 2016

Ellenberg H, Leuschner C (1996) Vegetation Mitteleuropas mit den Alpen, vol 1095. Ulmer, Stuttgart

Estrella N, Menzel A (2006) Responses of leaf colouring in four deciduous tree species to climate and weather in Germany. Clim Res $32: 253-267$
Feiccabrino J, Lundberg A (2008) Precipitation phase discrimination in Sweden. In: Pomeroy J (ed) 65th Eastern Snow Conference, Fairlee (Lake Morey), Vermont, USA, pp 239-254

Field CB et al (2014) IPCC, summary for policymakers climate change 2014: impacts, adaptation, and vulnerability Part A: global and sectoral aspects. In: Contribution of working group II to the fifth assessment report of the intergovernmental panel on climate change, pp 1-32

Fu YSH, Campioli M, Van Oijen M, Deckmyn G, Janssens IA (2012) Bayesian comparison of six different temperature-based budburst models for four temperate tree species. Ecol Model 230:92-100. https://doi.org/10.1016/j.ecolmodel.2012.01.010

Gerrits A, Pfister L, Savenije H (2010) Spatial and temporal variability of canopy and forest floor interception in a beech forest Hydrol Process 24:3011-3025

Geßler A, Keitel C, Kreuzwieser J, Matyssek R, Seiler W, Rennenberg H (2007) Potential risks for European beech (Fagus sylvatica L.) in a changing climate. Trees $21: 1-11$

Granier A, Bréda N, Biron P, Villette S (1999) A lumped water balance model to evaluate duration and intensity of drought constraints in forest stands. Ecol Model 116:269-283

Gunderson CA, Edwards NT, Walker AV, O'Hara KH, Campion CM, Hanson PJ (2012) Forest phenology and a warmer climate-growing season extension in relation to climatic provenance. Glob Change Biol 18:2008-2025

Häkkinen R, Linkosalo T, Hari P (1995) Methods for combining phenological time series: application to bud burst in birch (Betula pendula) in Central Finland for the period 1896-1955. Tree Physiol 15:721-726

Herbst M, Rosier PT, McNeil DD, Harding RJ, Gowing DJ (2008) Seasonal variability of interception evaporation from the canopy of a mixed deciduous forest. Agric Forest Meteorol 148:1655-1667

Hock R (2003) Temperature index melt modelling in mountain areas. J Hydrol 282:104-115. https://doi.org/10.1016/S0022 -1694(03)00257-9

IUSS Working Group W (2006) World reference base for soil resources, vol 103. World Soil Resources Report, Rome, Italy

Kirkpatrick S (1984) Optimization by simulated annealing-quantitative studies. J Stat Phys 34:975-986. https://doi.org/10.1007/ Bf01009452

Kljun N et al (2007) Response of net ecosystem productivity of three boreal forest stands to drought. Ecosystems 10:1039-1055

Kölling C, Zimmermann L, Walentowski H (2007) Klimawandel: was geschieht mit Buche und Fichte. AFZ-DerWald 11:584-588

Körner C, Basler D (2010) Phenology under global warming. Science 327:1461-1462. https://doi.org/10.1126/science.1186473

Kunstmann H, Schneider K, Forkel R, Knoche R (2004) Impact analysis of climate change for an Alpine catchment using high resolution dynamic downscaling of ECHAM4 time slices. Hydrol Earth Syst Sci Discuss 8:1031-1045

Laube J, Sparks TH, Estrella N, Höfler J, Ankerst DP, Menzel A (2014) Chilling outweighs photoperiod in preventing precocious spring development. Glob Change Biol 20:170-182. https://doi. org/10.1111/gcb. 12360

Lindner $\mathrm{M}$ et al (2010) Climate change impacts, adaptive capacity, and vulnerability of European forest ecosystems. Forest Ecol Manag 259:698-709

Mayer H, Holst T, Brugger U, Kirchassner A (2005) Trends of the forest significant climate variables air temperature and precipitation in south-west Germany from 1950 to 2000. Allg Forst Jagdztg 176:45-56

Menzel A, Estrella N, Heitland W, Susnik A, Schleip C, Dose V (2008) Bayesian analysis of the species-specific lengthening of the growing season in two European countries and the influence of an insect pest. Int J Biometeorol 52:209-218 
Mucina L, Grabherr G, Ellmauer T (1993) Die Pflanzengesellschaften Österreichs. Teil 3: Wälder und Gebüsche. Gustav-Fischer, Jena

Nash JE, Sutcliffe JV (1970) River flow forecasting through conceptual models part I-a discussion of principles. J Hydrol 10:282-290

Neumann $\mathrm{M}$ et al (2001) Waldzustandsmonitoring in Österreich: Ergebnisse der Intensivbeobachtungsflächen (Level II). Forstliche Bundesversuchsanstalt, Wien

Pearce AJ, Rowe LK (1981) Rainfall interception in a multi-storied, evergreen mixed forest: estimates using Gash's analytical model. J Hydrol 49:341-353

Peck A, Mayer H (1996) Einfluss von Bestandesparametern auf die Verdunstung von Wäldern. Forstwissenschaftliches Centralblatt vereinigt mit Tharandter forstliches Jahrbuch 115:1-9

Rennenberg H, Seiler W, Matyssek R, Gessler A, Kreuzwieser J (2004) Die Buche (Fagus sylvatica L.)-ein Waldbaum ohne Zukunft im südlichen Mitteleuropa. Allgemeine Forst-und Jagdzeitung 175:210-224

Richardson AD, Keenan TF, Migliavacca M, Ryu Y, Sonnentag O, Toomey M (2013) Climate change, phenology, and phenological control of vegetation feedbacks to the climate system. Agric Forest Meteorol 169:156-173

Schaber J, Badeck F-W (2002) Evaluation of methods for the combination of phenological time series and outlier detection. Tree Physiol 22:973-982

Schmid I (2002) The influence of soil type and interspecific competition on the fine root system of Norway spruce and European beech. Basic Appl Ecol 3:339-346

Schume H, Jost G, Katzensteiner K (2003) Spatio-temporal analysis of the soil water content in a mixed Norway spruce (Picea abies (L.) Karst.) —European beech (Fagus sylvatica L.) stand. Geoderma 112:273-287. https://doi.org/10.1016/s0016-7061(02)00311-7

Schume H, Jost G, Hager H (2004) Soil water depletion and recharge patterns in mixed and pure forest stands of European beech and Norway spruce. J Hydrol 289:258-274

Schwärzel K et al (2009) A novel approach in model-based mapping of soil water conditions at forest sites. Forest Ecol Manag 258:2163-2174

Sutmöller J, Spellmann H, Fiebiger C, Albert M (2008) Der Klimawandel und seine Auswirkungen auf die Buchenwälder in

\section{Affiliations}

\section{Klaus Dolschak ${ }^{1} \cdot$ Karl Gartner $^{2} \cdot$ Torsten W. Berger $^{1}$}

1 Department of Forest- and Soil Sciences, Institute of Forest Ecology, University of Natural Resources and Life Sciences (BOKU), Peter Jordan-Straße 82, 1190 Vienna, Austria
Deutschland. The effects of climate change on beech forests in Germany. Ergebnisse angewandter Forschung zur Buche 3:135-158

Swift LW (1976) Algorithm for solar-radiation on mountain slopes. Water Resour Res 12:108-112. https://doi.org/10.1029/Wr012 i001p00108

Tang J, Bolstad PV, Ewers BE, Desai AR, Davis KJ, Carey EV (2006) Sap flux-upscaled canopy transpiration, stomatal conductance, and water use efficiency in an old growth forest in the Great Lakes region of the United States. J Geophys Res Biogeosci 111:1-12

Tank AMGK et al (2002a) Daily dataset of 20th-century surface air temperature and precipitation series for the European Climate Assessment. Int J Climatol 22:1441-1453. https://doi. org/10.1002/joc. 773

Tank AMGK et al (2002b) Daily dataset of 20th-century surface air temperature and precipitation series for the European Climate Assessment. Int J Climatol. https://doi.org/10.1002/joc.773

Theurillat J-P, Guisan A (2001) Potential impact of climate change on vegetation in the European Alps: a review. Clim Change 50:77-109

van Wijk MT, Williams M (2005) Optical instruments for measuring leaf area index in low vegetation: application in Arctic ecosystems. Ecol Appl 15:1462-1470. https://doi.org/10.1890/03-5354

Vilhar U (2016) Comparison of drought stress indices in beech forests: a modelling study. Iforest 9:e1-e8

Vitasse Y, Basler D (2013) What role for photoperiod in the bud burst phenology of European beech. Eur J Forest Res 132:1-8. https:// doi.org/10.1007/s10342-012-0661-2

Vitasse Y, Porte AJ, Kremer A, Michalet R, Delzon S (2009) Responses of canopy duration to temperature changes in four temperate tree species: relative contributions of spring and autumn leaf phenology. Oecologia 161:187-198. https://doi.org/10.1007/s0044 2-009-1363-4

Publisher's Note Springer Nature remains neutral with regard to jurisdictional claims in published maps and institutional affiliations.

2 Department of Forest Ecology and Soil, Federal Research and Training Centre for Forests, Natural Hazards and Landscape, Seckendorff-Gudent-Weg 8, 1131 Vienna, Austria 